\title{
PRELIMINARY NOTICES OF SOME NEW PACIFIC CEPHALOPODS.
}

By S. Stillman Berry, of Stanford University, California.

Pending the publication in a forthcoming report of complete descriptions with the necessary figures, it has been thought best to present in advance brief diagnoses of certain West American squids and devilfish, which appear to be new in the collections at my disposal. Most of the material was obtained by the U. S. Bureau of Fisheries steamer Albatross. The region concerned is faunally a very rich one, but as its teuthology has been hitherto practically unknown, the fact that a number of its most common and characteristic species are undescribed need be in no way surprising.

\section{CIRROTEUTHIS MACROPE, new species.}

Body of rather small size, subgelatinous, elongate for a decapod, with a broad oar-like fin on either side. Mantle opening full and very wide, reaching to a point just behind each eye.

Head wide, flattened; eyes large and prominently protruding. Funnel large and broad, the funnel organ comprising a pair of small oval whitish pads, situated one at either side on the dorsal wall of the cavity near the apex.

Arms connected by a thin umbrella reaching nearly or quite to their tips; very delicate and not well preserved; suckers small, flanked on either side by a row of rather large papilla-like cirri.

Radula well developed, contrary to one of the supposed characteristics of the family Cirroteuthidæ. There are seven rows of teeth.

Type.-Cat. No. 214317, U.S.N.M. From Albatross station 4393, near San Diego, California.

Length (total) $99 \mathrm{~mm}$.; to base of umbrella $58 \mathrm{~mm}$.

\section{ELEDONELLA HEATHI, new species.}

Body smooth, inflated, of a semimembranous consistency; mantle opening very wide and full, extending slightly past the center of each eye. 
Head short, broad, compressed; eyes very large, lens much protruding. Funnel thin walled and broad; the funnel organ consisting of a tripartite pad shaped like an inverted $V$, its apex free and flap like.

Arms of moderate length, attenuate, the third pair much the largest and longest, the others nearly of a length; umbrella well developed; suckers in a single row, large, much elevated, and showing the peculiar constriction near the apex as observed in other species of the genus.

Gills very large, comprising about eight lamellæ.

Type.-Cat. No. 214318, U.S.N.M. From Albatross station 4396, off Santa Catalina Island, California.

Length (total) $117 \mathrm{~mm}$; of mantle $50 \mathrm{~mm}$.

\section{POLYPUS CALIFORNICUS, new species.}

Body of moderate size, short, rounded, compact; surface covered with numerous large stellate papillæ which become smaller and nearly obsolete ventrally; above each eye a rounded flattened tubercle slightly larger than the rest.

Head short and broad, separated from the body by a slight constriction; eyes of moderate size. Funnel rather long, conical, broadly adherent to the head for the greater part of its length.

Arms stout, moderately long, their length from two and one-half to three times that of the head and body; relative order of length variable; their basal quarter webbed. In the male the third right arm considerably shorter than the others; its hectocotylized portion large and prominent, narrowly and deeply channeled, the excavation distinctly rugose with numerous flattened transverse grooves and ridges. Suckers in two rows, rather large.

Color in alcohol a pinkish brown.

Type.-Cat. No. 214321, U.S.N.M. From Albatross station 4325, in the vicinity of San Diego, California.

Length (total) $308 \mathrm{~mm}$; posterior tip of body to base of dorsal arms $89 \mathrm{~mm}$.

\section{POLYPUS LEIODERMA, new species.}

Body of moderate size, wider than long; nearly smooth except for a few rather distant simple papillæ on the dorsal surface, as well as a narrow (though distinct) membranous fold bounding the outer periphery.

Head short and broad with large eyes. Funnel long and rather slender.

Arms not very long, their order 1, 2, 3, 4, the dorsal pair decidedly the stouter and longer, the ventral the reverse; umbrella well developed, extending between the dorsal and lateral arms for over a fourth of their length, but much shorter between the ventral pair; suckers in two rows, small, and relatively very numerous. 
Color very pale over the body; arms and umbrella darker.

Type.-Cat. No. 214322, U.S.N.M. From Albatross station 4293, Shelikof Strait, Alaska.

Length (total) $210 \mathrm{~mm}$; posterior tip of body to base of dorsal arms $45 \mathrm{~mm}$.

ROSSIA PACIFICA, new species. fins.

Body moderately small, sepioliform, with large subcordate lateral

Head large; arms stout and rather short, the order of length 3, 4, 2,1 ; umbrella rudimentary; suckers spherical, oblique, in two rows at the base and tip of all the arms, but often extremely crowded along the middle where they are apparently ranked in three or even four rows. Both dorsal arms in the male hectocotylized, strongly recurved, their suckers greatly reduced, usually in two rows until just before reaching the tip, when they become more crowded; the bases of the suckers transversely compressed to form a series of rugose folds. Tentacles variable in size and proportion, the club but slightly expanded; at the middle with about eight rows of small delicately toothed suckers.

Type.-Cat. No. 214323, U.S.N.M. From Albatross station 4233, Behm Canal, Alaska.

Length (total) $74 \mathrm{~mm}$.; length of mantle (dorsal) $32 \mathrm{~mm}$.

This species is nearly allied to R. macrosoma Delle Chiaje but appears to differ in a number of small details.

LOLIGO OPALESCENS, new species.

Body of moderate size, elongate, slightly swollen near the middle, thence tapering acutely to a rather sharp point; fins large, sagittate, about half as long as the mantle; mantle margin produced above into a prominent squarish rostrum.

Head small, square; eyes large.

Arms stout and rather short, unequal, the dorsal arms considerably the shortest; umbrella rudimentary, but keels and swimming membranes well developed, especially on the third arms where the ventral membrane becomes wider than the arm itself. Suckers small, notched above, regularly alternating in two rows; horny rings with 9 to 12 bluntly rounded squarish teeth. Left ventral arm of the male conspicuously hectocotylized; along the proximal two-thirds of the arm the suckers are unmodified, but along the distal third their pedicels become greatly elongate and transversely flattened; also the cupules undergo great reduction although persisting to the tips, those of the dorsal row being the most modified.

Tentacular club slightly expanded, with two lateral rows of small suckers and two median rows of large ones, the horny rings of the latter armed all round with about thirty-five small, rather elongate, bluntly conical teeth. 
Buccal membrane seven-pointed, each point bearing two rows of extremely minute toothed suckers.

Gladius broadly lanceolate, thin, its margins little if at all thickened.

Type.--In the Stanford University collection. From Puget Sound, Washington (shrimp fishermen). Ranges to San Diego, California.

Length (total) $177 \mathrm{~mm}$; of mantle (dorsal) $132 \mathrm{~mm}$; of fins $61.5 \mathrm{~mm}$.

\section{GALITEUTHIS PHYLLURA, new species.}

Body of moderate size, translucent, membranous, smooth; elongate and becoming excessively attenuate between the long narrow lanceolate fins; the latter as broad as the body, thin and leaf-like; mantle firmly attached to the head at three points as in G. armata.

Head small, rather elongate; eyes enormous, globular, sessile, with small openings.

Arms moderately short, their order $4,3,2,1$, each bordered by a delicate hyaline swimming membrane. Suckers small, subspherical, with smooth horny rings. Tentacles long; the club slightly expanded and armed with twelve delicate hooks besides a few minute suckers at the tip; fixing apparatus consisting of a group of about eight small suckers and as many pads on the carpal portion of the club, whence two rows of minute flattened suckers and pads alternate in pairs down the stalk nearly to the base.

Type.-Cat. No. 214325, U.S.N.M. From Albatross station 4529, Monterey Bay, California.

Length (total) $350 \mathrm{~mm}$; length of mantle (dorsal) $230 \mathrm{~mm}$.

Very close to G. armata Joubin from the Mediterranean. 


\section{$2 \mathrm{BHL}$ Biodiversity Heritage Library}

Berry, S. Stillman. 1911. "Preliminary notices of some new Pacific cephalopods." Proceedings of the United States National Museum 40(1838), 589-592. https://doi.org/10.5479/si.00963801.1838.589.

View This Item Online: https://www.biodiversitylibrary.org/item/53820

DOI: https://doi.org/10.5479/si.00963801.1838.589

Permalink: https://www.biodiversitylibrary.org/partpdf/53295

\section{Holding Institution}

Smithsonian Libraries

\section{Sponsored by}

Smithsonian

\section{Copyright \& Reuse}

Copyright Status: Public domain. The BHL considers that this work is no longer under copyright protection.

This document was created from content at the Biodiversity Heritage Library, the world's largest open access digital library for biodiversity literature and archives. Visit BHL at https://www.biodiversitylibrary.org. 